\title{
New records of postglacial walrus and a review of Quaternary marine mammals in New Brunswick
}

\author{
Randall F. Miller \\ Natural Sciences Division, New Brunswick Museum, 277 Douglas Avenue, \\ Saint John, New Brunswick E2K 1E5, Canada
}

Date Received December 13, 1989

Date Accepted February 2, 1990

\begin{abstract}
New records for postglacial walrus, Odobenus rosmarus, from New Brunswick raise the number of documented specimens in the province to nine. One of the previous reports was a tusk fragment, one was a partial cranium, one was an almost complete skeleton. Six new specimens are represented by partial or complete skulls. Three are from older collections of the New Brunswick Museum. Two of the most recent finds were dredged from the Bay of Fundy.

Walrus form part of a small Quaternary marine mammal fauna in New Brunswick. Three species of whale, beluga, narwhal and minke (?), as well as harp (?) seal and walrus, have been reported over the past century. However, only walrus and narwhal can be confirmed by existing specimens.

Marine mammal fossils from Quaternary deposits in New Brunswick demonstrate environmental requirements compatible with summer sea-surface temperatures postulated from earlier studies of littoral invertebrates. Radiocarbon dates associated with some of the marine mammals suggest they inhabited New Brunswick's coastal waters by at least 12,500 years B.P.
\end{abstract}

La mention de nouveaux spécimens du morse postglaciaire, Odobenus rosmarus, porte à neuf le nombre de ceux-ci connus au Nouveau-Brunswick. Un fragment de défense, un cranium partiel ainsi qu'un squelette presque complet avaient déjà été mentionnés. Six nouveaux spécimens sont représentés par des crânes plus ou moins complets. Trois d'entre eux proviennent de vieilles collections du Musée du Nouveau-Brunswick. Deux des trouvailles récentes furent draguées dans la baie de Fundy.

Les morses font partie d'une faunule de mammiferes marins quaternaires au Nouveau-Brunswick. Trois espèces de baleine, des bélugas, des narvals et des balénoptères, ainsi que des phoques (du Groenland?) et des morses ont fait l'objet de mentions au cours du siècle dernier. Cependant, les spécimens en existence ne permettent de confirmer que les morses et les narvals.

Les fossiles de mammiferes marins des dépôts quaternaires du Nouveau-Brunswick démontrent des besoins environnementaux compatibles avec les températures estivales de la surface de la mer postulées à partir d'études antérieures des invertébrés littoraux. Des datations radiochronologiques au $\mathrm{C}^{14}$ associées à certains des mammiferes marins suggèrent qu'ils habitaient le littoral du Nouveau-Brunswick il y a au moins 12,500 ans B.P.

[Traduit par le joumal]

\section{INTRODUCTION}

Marine mammal remains have been known from Pleistocene and Holocene deposits in New Brunswick since at least 1871, when Sandford Fleming's work crew recovered a nearly complete walrus skeleton from a gravel pit near Moncton. Only a few taxa have since been described in the literature. This paper summarizes the current state of knowledge of Quaternary marine mammal fossils from New Brunswick and reports six new records of postglacial walrus and two whales from this province, plus seven additional New Brunswick Museum walrus records from Atlantic Canada. Other marine mammal fossils from New Brunswick are reviewed. Harington and Occhietti (1988) included most of the New Brunswick specimens in a recent review of the marine mammals from the Champlain Sea and its approaches.
Quaternary vertebrate fossils are poorly documented in New Brunswick, especially because most of the finds were made more than fifty years ago. Detailed information about the stratigraphic setting or associated fossils does not always accompany specimens and in some cases specimens have been lost. Most mammal remains known from Quaternary deposits in New Brunswick were discovered and described in the late nineteenth or early twentieth century. J.B.Gilpin, a Nova Scotia physician, provided the first published description of an ice age narwhal in the Proceedings of the Nova Scotian Institute of Science (1874), although its occurrence had been noted earlier by Honeyman (1872). Matthew followed (1879) by describing a beluga whale and a harp (?) seal fossil in a report to the Geological Survey of Canada. Ganong $(1904,1906)$ described eighteenth (?) century walrus remains from a butchery near Miscou. Very little information is available for any of the specimens with the exception 
of Perkins' (1908) redescription of Gilpin's narwhal from. Jacquet River on New Brunswick's north shore. A whale vertebra from eastern New Brunswick represents the most recent, published specimen recovered (Rampton and Paradis, 1981).

Few of the marine mammals have been dated. One specimen of walrus from the collection described here has been radiocarbon dated and work is underway to determine chronological ages of individuals for at least some of the walrus specimens. Since this project to document known provincial occurrences began in 1987, several fossils have come to light. They are often found by fishermen and gravel-quarry operators. Undoubtedly the number of specimens reported will increase as more people are made aware of their significance.

\section{MARINE DEPOSITS AND STRATIGRAPHY}

During the Late Wisconsinan/Early Holocene, isostatic adjustment of land and changes in sea level resulted in the deposition of marine sediments of varying thickness in parts of New Brunswick (Fig. 1). Thick marine deposits are present along the Bay of Fundy, east and west of Saint John, and in the Bathurst Basin. Marine silty sand covers much of the New Brunswick Lowlands along the Gulf of St. Lawrence (Rampton et al., 1984) and elsewhere a thin veneer of marine sediments can be found. In the south, Gadd (1973) divided the deposits into two facies: a silty to clayey facies interpreted as resulting from deposition in deep, off-shore environments; and a sandy gravel facies deposited in high energy near-shore environments where waves reworked glaciofluvial sand and gravel. These are equivalents of the Leda clay and Saxicava sand respectively, described in older literature from the Champlain Sea and New Brunswick deposits (Dawson, 1893; Matthew, 1879). Thin layers of silt, silty clay and clay are often interbedded with dark grey to black sands and clayey deposits become interfingered with sand and gravel deposits toward shore (Gadd, 1973).

Marine mammal fossils have been found in both facies. The whale specimens, described below, have been recovered from clay, some below sand or sand and gravel, and in gravel. The seal specimen was found in black sand interbedded with marine clay. Some walrus specimens have been found in gravel, whereas other specimens have been dredged from the seafloor, so the nature of the enclosing sediment is uncertain.

Southern New Brunswick was probably ice-free by the Millville-Dungarvon phase of Wisconsin glaciation, about 12,700 years B.P. Most marine sediments were deposited prior to 12,300 years B.P. (Rampton et al., 1984). The known marine mammal occurrences are illustrated in Figure 1, where each occurrence is denoted by a numeral.

\section{NEW RECORDS OF WALRUS}

In addition to three records of postglacial walrus already published (Harington and Occhietti, 1988) the New Brunswick Museum houses four, previously unreported, New Brunswick specimens. All specimens are catalogued in the New Brunswick Museum (NBMG) unless stated otherwise. UNB numbers refer to the University of New Brunswick, Fredericton.
In August 1987, a partial skull of a walrus was recovered from the Bay of Fundy by a fisherman using a scallop drag (Fig. 1-3). The specimen came from a depth of about $80 \mathrm{~m}$. Drying and salt damage left the specimen in a deteriorated state. The skull was donated to the museum in 1988 where the ivory and bone were conserved (Day and Miller, 1989).

Description: Specimen (NBMG 4559), anterior cranium, composed of almost complete left tusk (LC1) and partial right tusk (RC1), left incisor (LI3), socket of right incisor (RI3), two left postcanines (LPC1,2) and the third postcanine socket (LPC3). The skull is preserved forward of the postorbital process of the malar. The tusks each measure about $180 \mathrm{~mm}$ circumference at the alveolar margin. Tusk length is at least $230 \mathrm{~mm}$ from alveolar margin to tip (Fig. 2a).

Conservation treatment made most of the skull unsuitable for carbon-14 dating, however, some fragments were retained for analysis. The accelerator mass spectrometry technique of radiocarbon analysis was used on a $1400 \mathrm{mg}$ sample of bone collagen to produce a date of $9,360 \pm 90$ years B.P. (TO-1554). The cranial fragments, slightly deteriorated and discoloured, were submitted untreated in field condition. The interior of the skull was packed with red marine clay and shells of the mollusc Astarte sp., fragmented oyster shells and other unidentified pelecypods plus a barnacle, Balanus crenatus. The same species from marine clays along the south coast of the Bay of Fundy and Gulf of Maine date at greater than 12,000 years B.P. (Nicks, 1988). Older shells may have been incorporated into the cranium as it was moved across the bottom of the bay.

Using the aging method described by Harington (1975) of measuring the tusk circumference at the alveolar margin, the skull appears to belong to a male walrus, at least 15 years of age.

A second skull was recovered from a beach near Beresford, northwest of Bathurst (Fig. 1-13). The exact circumstances of the find are still under investigation. Staining on the specimen indicates it was partially buried and exposed to marine waters. Recent barnacle growth can be seen in some skull cavities.

Description: Specimen (NBMG 4587) composed of a nearly complete cranium lacking teeth and tusks, some tooth sockets are partially preserved (Fig. 2 b).

The third skull fragment belongs to a juvenile walrus. It was collected from a gravel pit near Village St. Paul (Fig. 1-10).

Description: The specimen (NBMG 4585) consists of a partial anterior cranium, forward the infraorbital canal. The skull is without tusks. The right incisor socket (RI3) and three postcanine sockets are present as well as a right postcanine (RPC2) and left incisor (LI3). Three left postcanine sockets and one tooth (LPC2) are preserved. Two loose teeth were associated with the specimen. The skull is obviously from a young animal based on its size (Fig. 2c).

A chronological age determination will be attempted when sufficient comparative material is obtained. Records show that 


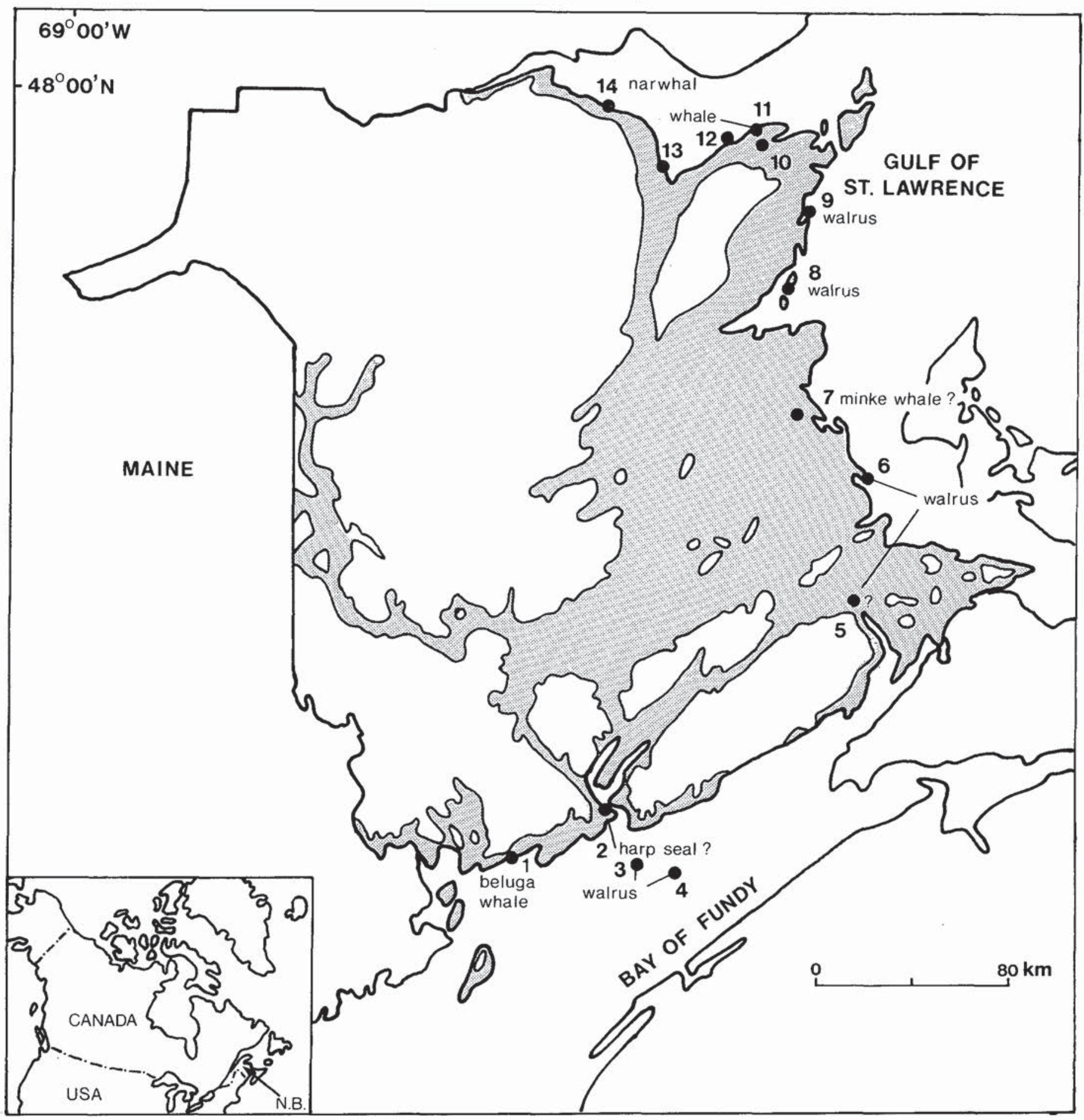

Fig. 1. Extent of Late Quaternary marine limits (shaded) in New Brunswick (from Rampton et al., 1984) and sites of postglacial marine mammal remains: (1) beluga, Pocologan River, (2) seal, Saint John, (3) walrus, Bay of Fundy, (4) walrus, Bay of Fundy, (5) walrus, Moncton, (6) walrus, Bouctouche, (7) minke, Kougibouguacis River, (8) walrus, Portage Island, (9) walrus, Tracadie, (10) walrus, Village St. Paul, (11) humpback (?), Grande Anse, (12) walrus, Clifton, (13) walnus, Beresford, (14) narwhal, Jacquet River.

at the same time fossil shells from Leda clay were also recovered from the same pit. The shell collection has not been located.

The fourth specimen from Portage Island, Miramichi Bay (Fig. 1-8), also appears to belong to a male walrus over 15 years of age. Information suggests it was found in a gravel pit (D.F.
McAlpine, personal communication, 1989) although this can not be confirmed.

Description: The nearly complete cranium (NBMG 4584), lacking portions of the posterior region, is worn smooth but well 

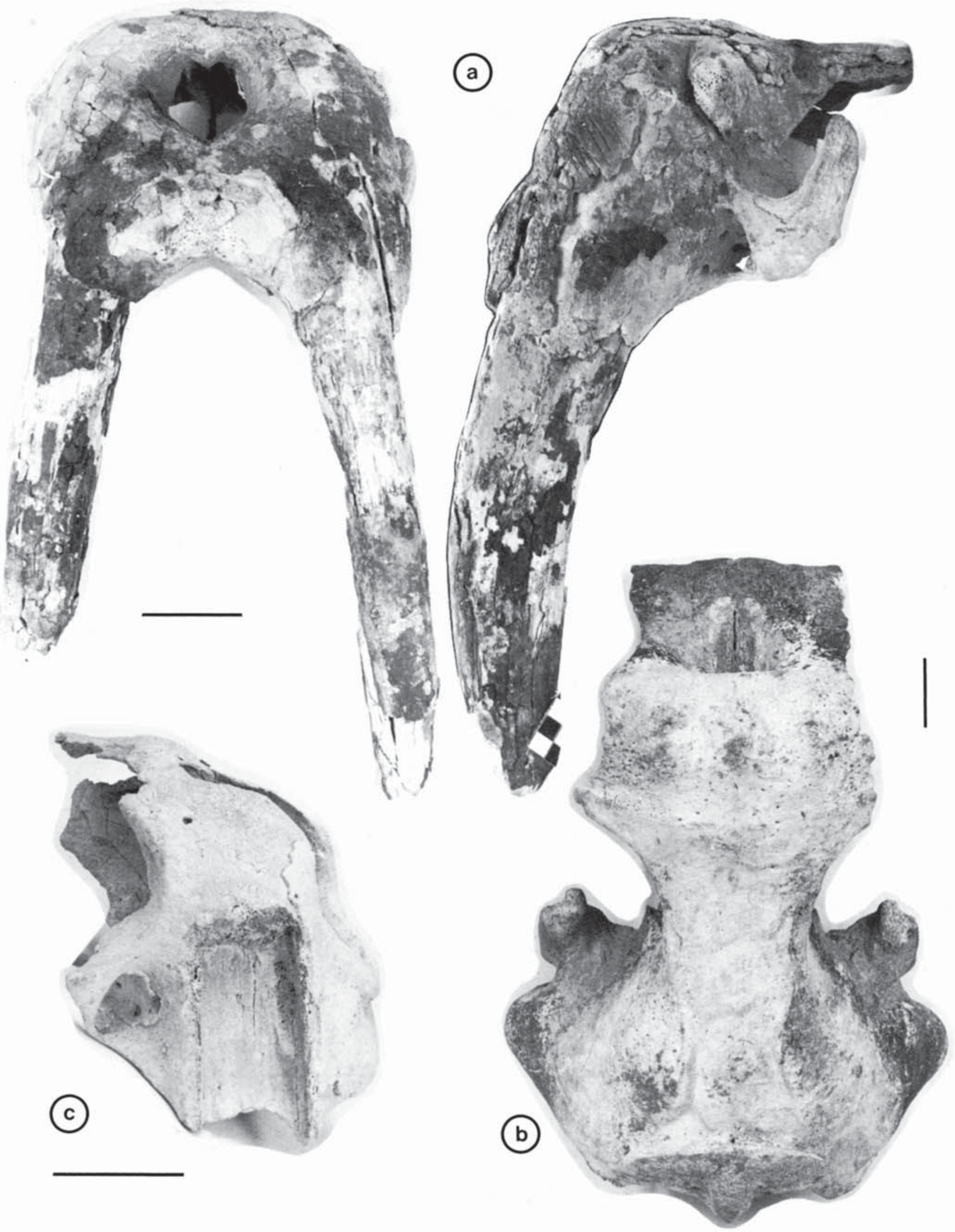

Fig. 2. Fossils of Odobenus resmarus from New Brunswick: (a) NBMG 4559, front and left side view of cranium, found south-southeast of Saint John; (b) NBMG 4587, top view of cranium, found near Beresford; (c) NBMG 4585, right side view of cranium showing tusk socket, found near Village St. Paul; (d) NBMG 4584, right side view of cranium, found on Portage Island, Miramichi Bay; (e) Huntsman Aquarium, bottom view of cranium, found $17.7 \mathrm{~km}$ from Black River, east of Saint John; (f) UNB F1055-2, Department of Anthropology, top view of lower jaw, found on Dune de Bouctouche. Scale bar is $5 \mathrm{~cm}$. 


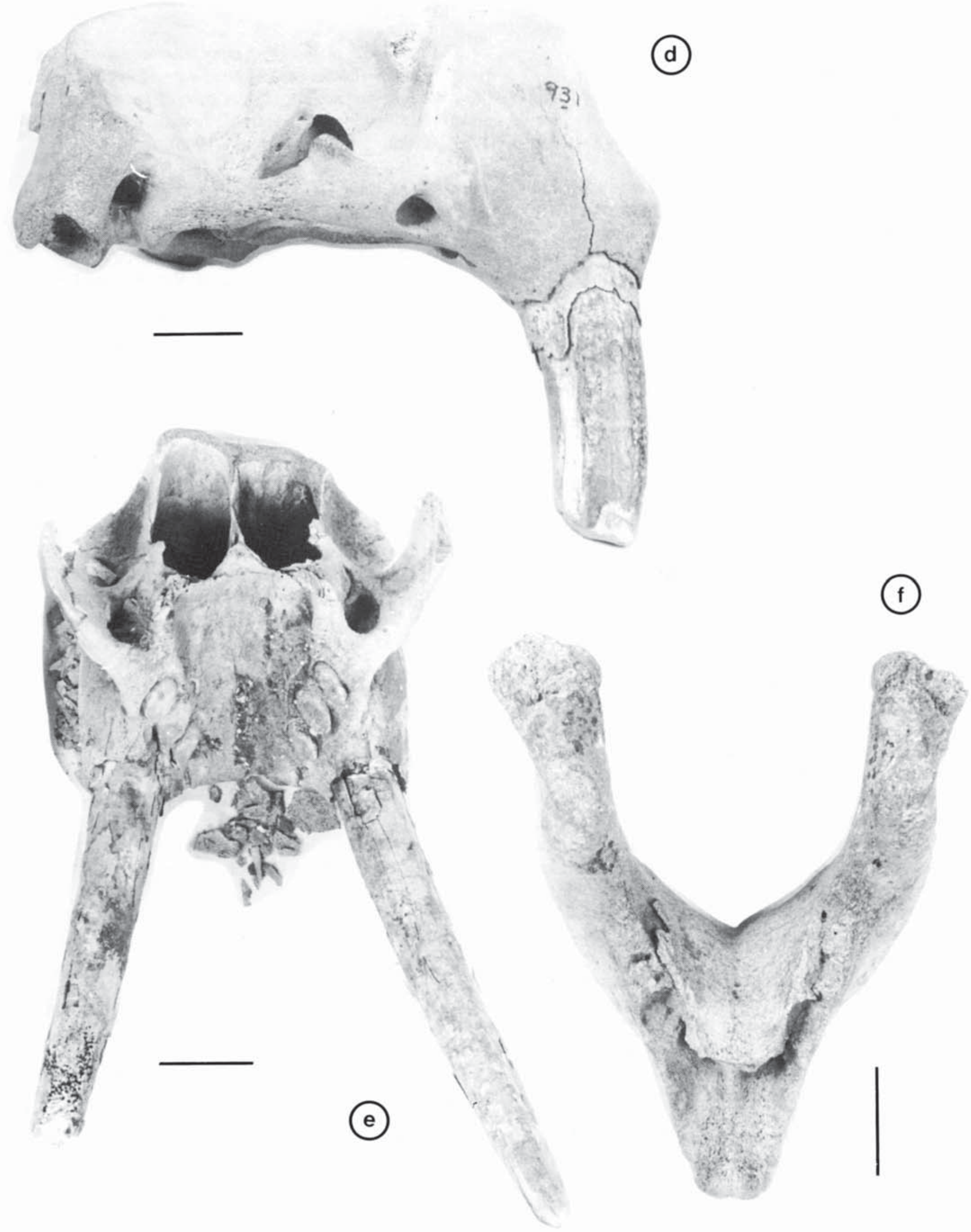

Figure 2 Cont. 
preserved with partial tusks ( $\mathrm{LC} 1$ and $\mathrm{RC} 1)$ and all other teeth. The tusks measure $160 \mathrm{~mm}$ ( $\mathrm{LCl}$, weathered) and $185 \mathrm{~mm}(\mathrm{RCl})$ in circumference at the alveolar margin and are at least $150 \mathrm{~mm}$ from margin to tip (Fig. 2d).

The third and fourth specimens reported above were donated in 1939 and 1968 respectively. They were found in the New Brunswick Museum's zoology collection and are now housed in the palaeontology collection.

Two specimens from other collections were examined. The first is a skull recovered by a scallop drag $17.7 \mathrm{~km}$ from Black River in the Bay of Fundy at a depth of $73 \mathrm{~m}$ (Fig. 1-4). The specimen (uncatalogued) is in the Huntsman Marine Aquarium, St. Andrews, New Brunswick.

Description: Almost complete cranium with complete dentition, including tusks. Tusks measure approximately $140 \mathrm{~mm}$ diameter at the alveolar margin and $220 \mathrm{~mm}$ from the margin to tip. The skull apparently belongs to a male walrus of about 12 years of age. The cranium is broken into two pieces about halfway along the malar bone (Fig. 2e).

The specimen is salt-damaged and will undergo conservation treatment. Exfoliated bone can be seen along the margins of the skull.

The second specimen is a lower jaw found in beach sands near Bouctouche in 1988 (Fig. 1-6). The specimen is in the Anthropology Department, University of New Brunswick, Fredericton.

Description: Specimen (F 1055-2 UNB) consists of lower jaw, minus teeth. It is heavily mineralized and water wom (Fig. 2f).

A summary of the new walrus records from New Brunswick is included (Table 1) with other unpublished New Brunswick Museum walrus records from Atlantic Canada. In addition to the walrus material, a sample of 11 bone fragments (NBMG 4586/111), labelled as walrus, were found in the New Brunswick Museum zoology collection. The material was recovered from a gravel pit near Grande Anse on the province's north shore (Fig. 1-11). The worn and fragmented remains belong to a large whale. The specimen was identified as an axis vertebra from a middlesized species, possibly a humpback whale, Megaptera novaeangliae.

A second large whale vertebra, from the UNB Anthropology Department (uncatalogued), was recovered from a load of gravel dumped in Fredericton. The source of the gravel has not been traced so its collection locality is unknown. This specimen is a lumbar vertebra and appears nearest in size to the fin whale, Balaenoptera physalus. Both specimens were identified on the basis of photographs (F.C. Whitmore, Jr., personal communication, 1989). Their condition and lack of diagnostic characters preclude the possibility of definite identification.

\section{REVIEW OF PREVIOUS RECORDS FROM NEW BRUNSWICK}

The remainder of the Quaternary marine mammal fauna from New Brunswick has been reported in previous publications. The list below updates the current state of knowledge. The modem distributions are based on information from Banfield (1981), Gaskin (1982) and Peterson (1966).

\section{Order CETACEA}

\section{Family BALAENOPTERIDAE Genus Balaenoptera}

Balaenoptera acutorostrata (Lacepéde)

1981 cf. Balaenoptera acutorostrata; Rampton and Paradis, p. 21.

1984 cf. Balaenoptera acutorostrata; Rampton et al.,pp. 32, 34.

Occurrence: Base of $2-4 \mathrm{~m}$ thick clay unit under veneer $(0.8 \mathrm{~m})$ of marine sand, south bank of Kouchibouguacis River, $1.5 \mathrm{~km}$ west of St-Louis-de-Kent (Fig. 1-7), elevation approximately 8 m (46º $\left.43.4^{\prime} \mathrm{N} ; 64^{\circ} 59.6^{\prime} \mathrm{W}\right)$.

Material: Vertebra, specimen used for C-14 dating, NMC 36170

Remarks: Specimen carbon-14 dated, 12,600 \pm 140 (GSC-3284; Blake, 1984) and $11,830 \pm 950$ (S-1969 (B)). Date of 18,570 \pm 500 (S-1969 (A)) apparently is erroneous. The minke whale occurs throughout the northem Atlantic and is fairly common in coastal waters of New Brunswick.

\section{Family MONODONTIDAE Genus Delphinapterus \\ Delphinapterus leucas (Pallas) \\ 1879 Beluga sp. ?; Matthew, 1879, p. 23 EE. \\ 1977 Delphinapterus leucas; Harington, p. 513. \\ 1988 Delphinapterus leucas; Harington and Occhietti, p. 53.}

Occurrence: Near the mouth of the Pocologan River, Charlotte

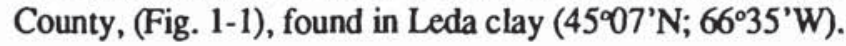

Material: A worn ramus of the lower jaw deposited in the museum of the Saint John Mechanics' Institute before 1879. Whereabouts of specimen unknown.

Remarks: Noted by Matthew (1879) as a right whale. Perhaps should have been "white" whale. Harington (1977) notes it as questionably referred to $D$. leucas. In Matthew's paper the location is listed as Popologan River. Although there is a Popelogan River in Restigouche County, northern New Brunswick he was referring to the Pocologan River in southem New Brunswick. The white whale occurs in eastern arctic waters from Ellsmere Island through Davis Strait to James Bay, along the 
Table 1. New records of Quaternary walrus (Odobenus rosmarus) from Atlantic Canada.

Catalogue No. and Part Locality and Remarks

NBMG 4559; anterior skull

adult male (?)

NBMG 4584; cranium adult male (?)

NBMG 4585; cranium juvenile

NBMG 4587; cranium

adult

Huntsman Aquarium;

cranium adult

F1055-2 UNB, Anthropology; lower jaw

NBMG 4588; tusk

NBMG 4583; tusk

NBMG 4589; tusk

NBMG 4590; tusk

NBMG 4591; tusk

NBMG 4592; tusk

NBMG 4593; tusk approx. $6.4 \mathrm{~km}$ SSE of Cape Spencer, N.B., from $80 \mathrm{~m}$ depth, collected by R.V. Hunter, 1987.

Portage Island, Miramichi Bay, Northumberland Co., N.B., possibly from gravel pit, collected by R.D. Young, 1968 .

Village St. Paul, Gloucester Co., N.B., gravel pit, Tomlinson Construction Co., collected by A. Theriault, 1939 (?).

from beach near Beresford, N.B., donated by G. Godin, 1980's.

17.7 km off Black River, N.B., scallop drag, donated by L. Bright, 1988 (?).

from beach sand, Dune de Buctouche, $46^{\circ} 31^{\prime} \mathrm{N} ; 64^{\circ} 40^{\prime} \mathrm{W}$, collected by M. Easterbrook, 1988.

off Pictou Island, N.S., Northumberland Strait, scallop drag, collected by R. Stewart, 1976.

near Pictou Island, N.S., scallop drag, collected in 1979.

near Granville Ferry, N.S., scallop drag, collected by R. Hallett, 1968.

$9.7 \mathrm{~km}$ NW Miminegash, P.E.I., from depth of $31 \mathrm{~m}$, scallop drag, collected by H. Doucett, 1971.

Georges Bank, $41^{\circ} 32 \mathrm{~N}$; $66^{\circ} 11^{\prime} \mathrm{W}$, scallop drag, collected by G. Fraelick, 1970.

Georges Bank, $41^{\circ} 32 \mathrm{~N} ; 66^{\circ} 11^{\prime} \mathrm{W}$, scallop drag, collected by F. Johnson, 1970.

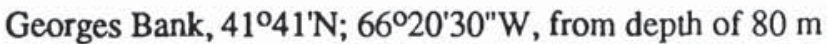
scallop drag, collected by V. Conrad, 1969. coast of Labrador and into the Gulf of St. Lawrence. An isolated population occurs in the St. Lawrence estuary. It has been recorded from the Bay of Fundy near Maces Bay (Fisher and Sergeant, 1954), probably an offshoot of the St. Lawrence River population (Sergeant and Fisher, 1957). A radiocarbon date on a combined sample of molluscs, Portlandia arctica, Mytilus edulis and cf. Serripes groenlandicus from Pocologan Harbour produced an age of $12,500 \pm 200$ (BGS 1258) years B.P. (A.A. Seaman, personal communication, 1988). This may indicate the approximate age of the whale specimen although the relationship of this sample to Matthew's fossil locality is uncertain.
Genus Monodon

Monodon monoceras Linnaeus

1874 whale; Gilpin, p. 400.

1872 whale; Honeyman, p. 597.

1874 whale; Honeyman, p. 219.

1893 Beluga catodon; Dawson, p. 268.

1905 Delphinapterus leucas Pallas; Lambe, p. 39.

1908 Monodon monoceras Linnaeus; Perkins, p. 139.

1977 Monodon monoceras; Harington, p. 514.

1988 Monodon monoceras; Harington and Occhietti, p. 54. 
Occurrence: Jacquet River, (Fig. 1-14), from cutting of Intercolonial Railway. In clay beneath (?) 12 feet of sand and gravel $\left(47^{\circ} 56^{\prime} \mathrm{N}\right.$; 66은.

Material: 23? bones presented to the Nova Scotia Museum, Halifax where they are currently housed. Catalogue Numbers 979GF143.0 to 979GF143.24. Collected by H. Townsend.

Remarks: The present distribution of the narwhal in North American waters is confined to areas north of the arctic circle between Greenland and mainland Canada from Ungava Bay to east of Ellsemere Island. A Carbon-14 date (Blake, 1983) on Hiatella arctica collected by Honeyman in 1874 from overlying sands yielded an age of $12,500 \pm 170$ (GSC-1557). This wascited by Blake (1983) as Beluga sp., an incorrect generic classification.

\section{Order PINNIPEDIA}

Family ODOBENIDAE

Genus Odobenus

\section{Odobenus rosmarus}

1985

Odobenus rosmarus; Harington, p. 196.

1988 Odobenus rosmarus; Harington and Occhietti, p. 56, fig. 8 .

Occurrence: In gravel ballast pit near Moncton (Fig. 1-5), probably found by workers under the supervision of Sandford Fleming, about 1871, during construction of the Intercolonial Railway.

Material: Nearly complete skeleton, on display in Biology Department at Queen's University, Kingston, Ontario. Not catalogued.

Remarks: Restored in 1983 by the National Museum of Natural Sciences, Paleobiology Division, Ottawa. The present distribution of the eastern subspecies, the Atlantic walrus, does not include the Bay of Fundy. However, historic records are known from northern New Brunswick, the Magdalen Islands, western Nova Scotia and Sable Island.

\section{Odobenus rosmarus; Harington, p. 256. \\ 1977 Odobenus rosmarus; Harington, p. 517. \\ 1988 Odobenus rosmarus; Harington and Occhietti, p. 56.}

Occurrence: From gravel pit approximately 100 yards from Chaleur Bay, Clifton (Fig. 1-12).

Material: Tusk, lacking tip. In possession of R. Duguay, Caraquet.

Remarks: According to Harington (1977) presumably from a layer of marine mollusc shells occurring 9 to $12 \mathrm{~m}$ below the surface.

\section{Odobenus rosmarus}

1977 Odobenus rosmarus; Harington, p. 517.

1988 Odobenus rosmarus; Harington and Occhietti, p. 56.

Occurrence: From offshore bar, east of Tracadie (Fig. 1-9).

Material: Anterior cranial fragment, worn third incisors and partial right tusk, Canadian Museum of Nature, Ottawa, Ontario, NMC 10426. Collected by J.M. Pauline.

Remarks: On display at the Canadian Museum of Nature, Ottawa, Ontario.

\section{Family PHOCIDAE}

Genus Phoca

Phoca sp.

1879 Phoca gröenlandica Muller; Matthew, p. 23 EE.

1977 Phoca; Harington, p. 522.

1988 Phoca; Harington and Occhietti, p. 59.

Occurrence: From black sand in lower Leda clay, Hopkins Brickyard, (Fairville) Saint John (Fig. 1-2), (45²0’ N; 6550’W).

Material: Destroyed in 1877 fire in Saint John, New Brunswick.

Remarks: Possibly Phoca (Pagophilus) gröenlandica. Skull and hind limbs nearly perfect, 15 large vertebrae with corresponding ribs and a number of caudal vertebrae. Harp seals are known from the North Atlantic. Although Banfield (1981) indicates that this species does not occur in the Bay of Fundy, there is at least one record from Mary's Point, near Moncton. Several extralimital records occur on the New England coast (McAlpine and Walker, in press).

\section{DISCUSSION}

\section{Walrus fossils in New Brunswick}

Two subspecies of walrus occur in North America. Odobenus rosmarus rosmarus, the Atlantic walrus and $O$. rosmarus divergens, the Pacific walrus are believed to have originated during the time of Pleistocene glaciation which split a previously single population (Harington, 1966). The two populations developed in isolation and can now be recognized as separate subspecies (Davies, 1958). A recent review of the Atlantic walrus has been published by Richard and Campbell (1988).

Postglacial walrus remains have been known from the east coast of North America since the middle nineteenth century (Hay, 1923; Provencher, 1869; Rhoads, 1898). Fossil remains have been found along the coast of Atlantic Canada and as far south as North Carolina (Gallagher et al., 1989; Kurtén and Anderson, 1980). Walrus feed in relatively shallow water, diving to about $80 \mathrm{~m}$ to scoop molluscs off the bottom. In a study of the biology of the Atlantic walrus, Mansfield (1958) listed in their diet the pelecypods; Mya truncata, Cardium, Hiatella arctica and Astarte borealis, and the gastropods; Buccinum and Natica. These same molluscs evidently comprised much of the Pleistocene marine fauna in New Brunswick and perhaps were a source 
of food for walrus discussed here. The New Brunswick walrus specimens described above are probably of postglacial origin based on their mode of occurrence. However, some may be as young as the seventeenth or eighteenth century.

Although walrus fossils have been known since the last century, it is still important to document their occurrence and develop a program to date the specimens: this will permit investigation of the development of the Atlantic walrus through time and the discovery of more about the range of walrus during the late Quaternary. Only by acquiring good collections of specimens can morphological and distribution differences be examined.

\section{Marine mammal fossils and radiocarbon dates}

Seven species of marine mammals have so far been reported from Quaternary deposits in New Brunswick, but only two, walrus and narwhal, can be confidently ascribed to a particular species. Two of the specimens from the Bay of Fundy coast, the beluga and the harp (?) seal, were lost or destroyed and identification rests with determinations made by G.F. Matthew. Harington and Occhietti (1988) reported Matthew's seal specimen as Phoca sp. and Harington (1977) noted the beluga identification as questionable. Both the humpback and fin whale identifications reported here must also be considered questionable due to a lack of diagnostic remains. The minke whale reported by Rampton and Paradis (1981) was only tentatively identified as Balaenoptera cf. B. acutorostrata.

Other than walrus, only one of the marine mammal specimens, Balaenopter $\mathrm{cf}$. B. acutorostrata has been radiocarbon dated. It yielded a date of about 12,000 years B.P. The narwhal (Monodon monoceras) was described by Gilpin (1874) in association with shells of Saxicava (Hiatella arctica), Mya, and Macoma. Blake (1983) and Rampton et al. (1984) reported a carbon-14 date of $12,500 \pm 170$ (GSC-1557) years B.P. for Hiatella arctica collected from the original site by D. Honeyman in 1874. Mya arenaria from the same area (Rampton et al., 1984) yielded a date of $12,500 \pm 130$ (GSC-3552) years B.P. suggesting a probable age for the narwhal.

Phoca sp., the seal, was described by Matthew (1879) as occurring in a black sand layer within clay with Mytilus edulis and other molluscs. At nearby Sheldon Point, in Saint John, $M$. edulis has been dated at $12,650 \pm 175$ (GX12971) years B.P. (Nicks, 1988). Hiatella arctica valves from Sheldon Point are dated at $13,100 \pm 160$ (GSC-3557) and 13,900 \pm 620 (GSC-3354) years B.P. (Rampton et al., 1984) suggesting a Late Wisconsinan age for the seal specimen.

No report of associated faunas was cited by Matthew (1879) for the beluga whale specimen from the Pocologan River although it was collected from a clay bank. A recent radiocarbon analysis on shells from Pocologan Harbour dates at 12,500 \pm 200 years B.P. (BGS 1258) (A.A. Seaman, personal communication, 1988), again suggesting the beluga specimen might be Late Wisconsinan.

Two walrus specimens from New Brunswick have been radiocarbon dated. The Moncton walrus has been dated at 9,700 \pm 130 years B.P. (Beta-16161) (C.R. Harington, personal com- munication, 1989). One of the walrus specimens dredged from the Bay of Fundy produced a date of $9,360 \pm 90$ years B.P. (TO1554). The juvenile walrus specimen from Village St. Paul was possibly associated with shells of Leda clay. Rampton $e t$ al. (1984) reported shell dates from that area of around 12,500 years B.P.

\section{Paleoclimatic significance}

Between 13,000 and 12,000 years ago ice retreated from most of New Brunswick and most marine sediments were likely deposited before 12,300 years B.P. (Rampton et al., 1984). Radiocarbon dates for marine mammals or nearby shell faunas suggest that narwhal, minke, seal and possibly beluga and walrus inhabited New Brunswick coastal waters shortly after deglaciation and that at least walrus inhabited the Bay of Fundy until about 9,400 years ago. Some of these species no longer inhabit this region. The narwhal presents the greatest alteration in range. It is the only marine mammal discussed that is not known historically from New Brunswick waters.

Belugas have been sighted in the Bay of Fundy as recently as 1954 (Fisher and Sergeant, 1954) and 1972 (Gaskin, 1982). Sergeant and Fisher (1957) suggested that belugas may stray from the St. Lawrence River population. Although harp seals are not known to breed in the Bay of Fundy, rare occurrences are known (McAlpine and Walker, in press). Historic records for walrus indicate its distribution extended farther south (Ganong, 1904, 1906) and probable strays are recorded off the western end of Nova Scotia (Wright, 1951).

Bousfield and Thomas (1975) speculated on postglacial changes in near surface ocean temperatures based on the distribution of littoral marine invertebrates in the Maritimes. Their data demonstrated that between 13,000 and 12,000 years B.P., as ice retreated from most of New Brunswick, water temperatures adjusted to changing currents and sea levels (Fig. 3). During this time the Strait of Belle Isle opened to allow cold subarctic $\left(<12^{\circ} \mathrm{C}\right.$ summer) waters to penetrate along the St. Lawrence River valley and into the Champlain Sea, including the Bay of Chaleur where remains of narwhal occur. An area of cold water also persisted along the north shore of the Bay of Fundy, eventually disappearing by 9,500 years B.P. Similar surface water temperatures occur today in the St. Lawrence estuary where the present beluga population survives and also near the mouth of the Bay of Fundy where recent sitings of beluga have been recorded.

According to Bousfield and Thomas (1975), areas of subarctic surface temperatures $\left(<12^{\circ} \mathrm{C}\right.$ summer) at 12,500 years B.P. would have included the sites where beluga whale, seal and walrus are recorded. Although environmental effects on marine mammal distribution are not completely understood, sea-surface temperature is used as a parameter in studies of cetacean zoogeography (Gaskin, 1982).

The fossil versus modem distribution of the few species of marine mammals recorded for New Brunswick appears consistent with the surface water temperatures postulated by Bousfield and Thomas (1975) based on their study of littoral invertebrates. However, more detailed information on marine mammals with respect to their tolerances of sea-surface temperatures, sea-ice, 


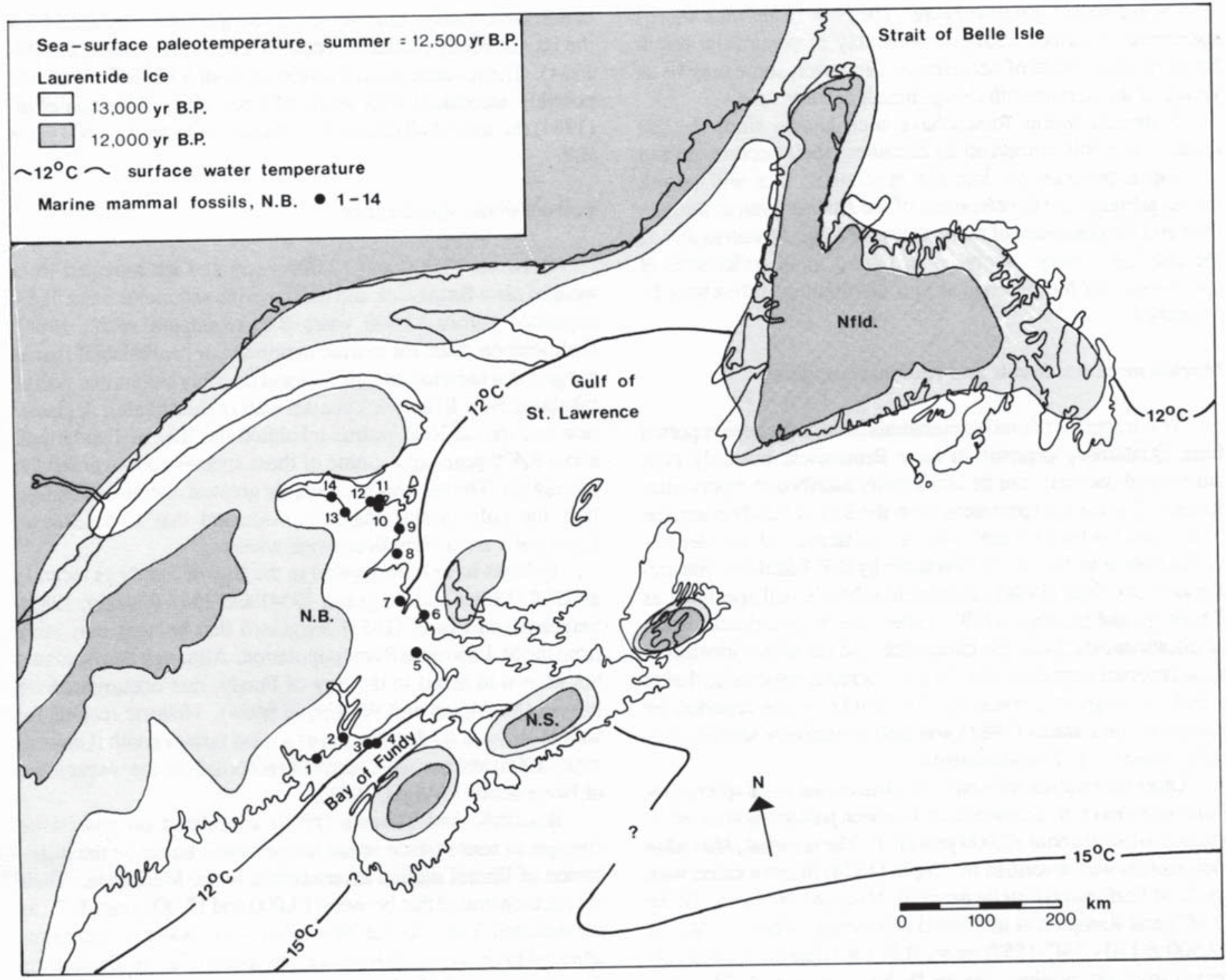

Fig. 3. Suggested ice margins (Dyke and Prest, 1987) and sea-surface temperature isotherms (Bousfield and Thomas, 1975) during late glacial times in southeastern Canada and related New Brunswick marine mammal sites discussed in text. Numbered sites correspond to Figure 1. Nfld. Newfoundland, N.B. - New Brunswick, N.S. - Nova Scotia.

water depth and food resources will have to be compiled to more fully examine the comparison.

\section{ACKNOWLEDGEMENTS}

This research was made possible with the assistance of $F$. Stewart (University of New Brunswick) and J. McElman (Huntsman Marine Aquarium) who made specimens available for loan. C. Day (New Brunswick Museum) developed a conservation treatment for salt damaged subfossil walrus bone. D. McAlpine (NBM) provided valuable assistance by transferring specimens from the museum's zoology collection and with identification. F. Whitmore, Jr., (United States National Museum) provided the identification of whale remains, and C.R. Harington (Canadian Museum of Nature) and A. Dyke (Geological Survey of Canada) helped by reviewing versions of the manuscript. A. Seaman (New Brunswick Department Natural Resources and Energy) as- sisted with the understanding of the geology of parts of New Brunswick. Thanks are also due to the many people who collected specimens.

BANFIELD, A.W.F. 1981. The Mammals of Canada. University of Toronto Press, Toronto, $438 \mathrm{p}$.

BLAKE, W., JR. 1983. Geological Survey of Canada Radiocarbon Dates XXIII. Geological Survey of Canada, Paper 83-7, 34 p. - 1984. Geological Survey of Canada Radiocarbon Dates XXIV. Geological Survey of Canada, Paper 84-7, 34 p.

BOUSFIELD, E.L. and THOMAS, M.L.H. 1975. Postglacial changes in distribution of littoral marine invertebrates in the Canadian Atlantic region. Proceedings Nova Scotian Institute of Science, 27, Supplement 3, pp. 47-60.

DAVIES, J.L. 1958. Pleistocene geography and the distribution of northem pinnipeds. Ecology, 39, pp. 97-113.

DAWSON, J.W. 1893. The Canadian Ice Age. W.V. Dawson, Montreal, $301 \mathrm{p}$. 
DAY, C. and MILLER, R.F. 1989. Conservation of semi-fossil postglacial walrus bone. Programme and Abstracts, Society for the Preservation of Natural History Collections, Drumheller and Calgary, Fourth Annual Meeting, p. 17.

DYKE, A.S. and PREST, V.K. 1987. Paleogeography of northern North America, 18,000 - 5,000 years ago. Geological Survey of Canada, Map 1703A, scale 1:12 500000.

FISHER, H.D. and SERGEANT, D.E. 1954. A record of a white whale in the Bay of Fundy. Canadian Field Naturalist, 68, pp. 138-139.

GADD, N.R. 1973. Quaternary geology of southwest New Brunswick with particular reference to Fredericton area. Geological Survey of Canada, Paper 71-34, 31 p.

GALLAGHER, W.B., PARRIS, D.C., GRANDSTAFF, B.S., and DETAMPLE, C. 1989. Quaternary mammals from the continental shelf off New Jersey. The Mosasaur, 4, pp. 101-110.

GANONG, W.F. 1904. The walrus in New Brunswick. Bulletin of the Natural History Society of New Brunswick, 22, pp. 240-241.

1906. On semi-fossil walnus bones from Miscou and elsewhere in New Brunswick. Bulletin of the Natural History Society of New Brunswick, 24, pp. $462-464$.

GASKIN, D.E. 1982. The Ecology of Whales and Dolphins. Heinemann, London, 459 p.

GILPIN, J.B. 1874. Observations on some fossil bones found in New Brunswick. Transactions of the Nova Scotian Institute of Science, 3, pp. $400-404$.

HARINGTON, C.R. 1966. Extralimital occurrences of walruses in the Canadian Arctic. Journal of Mammalogy, 47, pp. 506-513.

- 1975. A Postglacial walrus (Odobenus rosmarus) from Bathurst Island, Northwest Territories. Canadian Field-Naturalist, 89. pp. 249-261.

1977. Marine mammals in the Champlain Sea and the Great Lakes. Annals of the New York Academy of Sciences, 288, pp. 508-537.

- 1985. Comments on Canadian Pleistocene mammals. Acta Zoologica Fennica, 170, pp. 193-197.

HARINGTON, C.R. and OCCHIETTI, S. 1988. Inventaire systématique et paléoécologie des mammiferes marins de la Mer de Champlain (fin du Wisconsinien) et de ses voies d'accès. Géographie physique et Quatemaire, 42, pp. 45-64.

HAY, O.P. 1923. The Pleistocene of North America and its vertebrated animals from the states east of the Mississippi River and from the Canadian provinces east of longitude $95^{\circ}$. Carnegie Institution of Washington, Publication 322, 499 p.

HONEYMAN, D. 1872. Skeleton of a whale in the Quaternary of New Brunswick. American Joumal of Science, 3, p. 597.

1874. On the Quatemary containing the New Brunswick fossil cetacean; on Niagara coral reefs; and on Niagara fossils in trap. American Journal of Science, 8, pp. 219-220.

KURTEN, B. and ANDERSON, B. 1980. Pleistocene mammals of North America. Columbia University Press, New York, 442 p.

LAMBE, L.M. 1905. The progress of vertebrate palaeontology in Canada. Transactions of the Royal Society of Canada, 5 (4), pp. 1356.

MANSFIELD, A.W. 1958. The biology of the Atlantic walrus Odobenus rosmarus rosmarus (Linnaeus) in the eastem Canadian Arctic. Manuscript Report Series (Biology) 653, 146 p.

MATTHEW, G.F. 1879. Report on the surficial geology of southern New Brunswick. Geological Survey of Canada, Report of Progress 1877-78, Pt. EE, pp. 1-36.

MCALPINE, D.F. and WALKER, R.H. In press. Extralimital records of the Harp Seal, Phoca groenlandica, from the western North Atlantic: A review. Marine Mammal Science.

NICKS, L.P. 1988. The Study of the Glacial Stratigraphy and Sedimentation of the Sheldon Point Moraine, Saint John, New Brunswick. Unpublished M.Sc. thesis, Dalhousie University, Halifax, Nova Scotia

PERKINS, G.H. 1908. On a skeleton of a whale in the Provincial Museum, Halifax, Nova Scotia; with notes on the fossil cetacea of North America. Proceedings and Transactions of the Nova Scotian Institute of Science, 12, Pt. 2, pp. 139-163.

PETERSON, R.L. 1966. The Mammals of Eastem Canada, Oxford Press, Toronto, $465 \mathrm{p}$.

PROVENCHER, L. 1869. Un morse fossile. Naturaliste Canadien, 2, pp. 19.

RAMPTON, V.N. and PARADIS, S. 1981. Quatemary geology of Moncton map area (21 1) New Brunswick. Natural Resources New Brunswick, Map Report 81-2, 77 p.

RAMPTON, V.N., GAUTHIER, R.C., THIBAULT, J., and SEAMAN, A.A. 1984. Quaternary Geology of New Brunswick. Geological Survey of Canada, Memoir 416.

RHOADS, S.N. 1898. Notes on the fossil walrus of eastern North America. Proceedings of the Academy of Natural Science of Philadelphia, 50, pp. 196-201.

RICHARD, P.R. and CAMPBELL, R.R. 1988. Status of the Atlantic Walrus, Odobenus rosmarus rosmarus, in Canada. Canadian Field-Naturalist, 102, pp. 337-350.

SERGEANT, D.E. and FISHER, H.D. 1957. The smaller Cetacea of Eastern Canadian waters. Journal of the Fisheries Research Board of Canada, 14, pp. 83-115.

WRIGHT, B.S. 1951. A walrus in the Bay of Fundy; The first record. The Canadian Field-Naturalist, 65, pp. 61-64. 